\title{
STUDI KEMAMPUAN LITERASI KIMIA MAHASISWA PENDIDIKAN KIMIA PADA MATERI PENGELOLAAN LIMBAH
}

\author{
Pandu Jati Laksono \\ Universitas Islam Negeri Raden Fatah Palembang \\ E-mail: pandujati_uin@radenfatah.ac.id
}

\begin{abstract}
Abstrak: Kemampuan literasi kimia merupakan salah satu kemampuan yang penting untuk dimiliki oleh calon pendidik di era moderen saat ini. Penelitian ini bertujuan untuk mengetahui ketercapaian kemampuan literasi kimia pada aspek pengetahuan, aspek konteks, aspek kompetensi, dan aspek sikap. Penelitian ini merupakan penelitian deskriptif kuantitatif dengan populasi yang terdiri dari mahasiswa pendidikan kimia UIN Raden Fatah. Subjek dalam penelitian ini sebanyak 50 mahasiswa yang telah menerima mata kuliah pengelolaan laboratorium. Teknik pengumpulan data dalam penelitian ini adalah wawancara dan angket. Instrumen penelitian data yang digunakan adalah pedoman wawancara dan lembar angket. Berdasarkan hasil penelitian yang telah dilakukan diketahui bahwa kemampuan literasi kimia mahasiswa kimia pada materi pengelolaan limbah sebesar 73,33\%. Hasil tersebut menunjukan bahwa kemampuan literasi kimia mahasiswa pendidikan kimia pada materi pengelolaan limbah tergolong sedang.
\end{abstract}

Kata kunci: literasi kimia, pengelolaan limbah

\section{PENDAHULUAN}

Pendidikan merupakan pondasi dasar dari kemajuan suatu bangsa, tidak ada bangsa yang maju apabila bangsa tersebut tidak memperhatikan bidang pendidikan. Pendidikan dalam UU No. 20 Tahun 2003 adalah usaha sadar dan terencana untuk mewujudkan suasana belajar dan proses pembelajaran agar siswa secara aktif mengembangkan potensi dirinya untuk memiliki kekuatan spiritual, keagamaan, pengendalian diri, kepribadian, kecerdasan, akhlak mulia, serta keterampilan yang diperlukan dirinya di dalam masyarakat, bangsa dan negara.

Kemajuan ilmu pengetahuan dan teknologi belakangan ini menjadi isu yang sangat penting dalam era globalisasi ini. Pendidikan dewasa ini harus memperhatikan dan mengikuti perkembangan zaman dan ilmu pengetahuan yang ada di era globalisasi ini. Kemajuan ilmu pengetahuan dan teknologi informasi, perkembangan pendidikan semakin mengalami perubahan dan mendorong berbagai usaha perubahan yang lebih baik.

Proses pendidikan diharapkan mampu membentuk manusia yang melek sains dan teknologi seutuhnya. Menurut sumartati (2009) pendidikan diharapkan berperan sebagai jembatan yang akan menghubungkan individu dengan lingkungannya ditengah-tengah era globalisasi yang semakin berkembang, sehingga individu mampu berperan sebagai sumber daya manusia yang berkualitas.

Peran literasi juga menjadi patokan kemajuan suatu masyarakat yang memiliki dampak panjang dalam peningkatan daya saing. Literasi menyumbang pengaruh besar terhadap sosial ekonomi. Oleh karena literasi berkaitan langsung dengan pengembangan sumber daya manusia. Ketika literasi menjadi proses penting setiap manusia sebelum manusia dapat mengakses pengetahuan dengan baik, dapat dikatakan literasi menjadi indikator kualitas hidup setiap manusia. Dan pada akhirnya, pemerataan literasi mendukung pengentasan kemiskinan

Literasi sains sebenarnyabukanlah hal baru dalam dunia pendidikan. 
Namun, sejak dua dekadeterakhir, literasi sains menjadi topik utamadalam setiap pembicaraan mengenaitujuan pendidikan sains di sekolah. Lederman (2014) menyatakan literatur dalam bidang pendidikan sainsjuga menunjukkan bahwa literasi sainssemakin diterima dan dinilai oleh parapendidik sebagai hasil belajar yang diharapkan.

Hasil PISA terhadap komponen literasi sains tahun 2000 menempatkan Indonesia pada peringkat 38 dari 41 negara dengan skor 393. PISA 2003 menyatakan bahwa prestasi literasi sains Indonesia terletak pada peringkat 38 dari 40 negara dengan skor 395. PISA 2006 menempatkan Indonesia pada posisi 50 dari 57 negara dengan skor 393. Prestasi literasi sains Indonesia pada PISA tahun 2009 ada pada 10 besar terbawah dari 65 negara. Survey PISA 2012 menyatakan bahwa literasi sains Indonesia turun dr posisi 54 ke posisi 64 dari 65 negara dengan skor 382. Hasil survey terakhir dari PISA tahun 2015, menempatkan Indonesia pada posisi 62 dari 70 negara dengan skor 403 (OECD, 2016).

Dalam menilai literasi kimiadapat menggunakan kesesuaian antara kerangkapenilaian literasi sains PISA dan kerangkaShwartz et al. (2005, 2006). Aspek Literasi Sains/kimiadalam Asessmen PISA 2015 dideskripsikan dalam Tabel 1.

Tabel 1. Aspek Literasi Sains/Kimia dalam Asesmen PISA 2015

\begin{tabular}{ll}
\hline Aspek & Deskripsi \\
\hline Pengetahuan (knowledge) & Isu-isu personal, lokal/nasional, dan global. Bisa berupa isu- \\
& isu yang terjadi saat ini atau isu-isu yang sudah terjadi yang \\
& membutuhkan pemahaman sains dan teknologi.
\end{tabular}

Konteks (context)

Kompetensi (competency)

Sikap (attitudes)
Pemahaman akan fakta-fakta utama, konsep dan teori penjelasan yang membangun landasan pengetahuan ilmiah. Pengetahuan berupa pengetahuan tentang alam semesta dan artefak teknologi (content knowledge), pengetahuan bagaimana gagasan-gagasan dihasilkan (procedural knowledge), dan pemahaman tentang rasional yang melandasi prosedur tersebut dan justifikasi penggunaannya (epistemic knowledge)

Kemampuan untuk menjelaskan fenomena secara ilmiah, mengevaluasi dan mendesain inkuiri ilmiah

Seperangkat sikap terhadap sains yang ditunjukkan dengan minat terhadap sains dan teknologi, menilai pendekatan ilmiah terhadap suatu inkuiri yang cocok, dan persepsi serta kesadaran akan isu-isu lingkungan.

Rendahnya literasi sains atau literasi kimia di Indonesia bisa ditingkatkan dengan perbaikan di bidang pendidikan. Bidang pendidikan memang menjadi tumpuan harapan bagi peningkatan kualitas sumber daya manusia (SDM) di Indonesia. Calon pendidik adalah salah satu komponen penting dalam bidang pendidikan karena calon pendidik merupakan cikal bakal pengajar/guru yang nantinya akan membantu peserta didik mengembangkan literasi kimia. Calon 
pendidik harus memiliki kemampuan menerapkan literasi kimia dengan beberapa pendekatan atau model pembelajaran, dan mengembangkan soal-soal serta instrumenevaluasi yang dapat meningkatkan kemampuan literasi kimia peserta didik. Untuk mengetahui perkembangan kemampuan literasi kimia peserta didik, tentu perlu diketahui terlebih dahulu bagaimana kemampuan literasi yang telah mereka miliki. Oleh karena itu, penelitian ini bertujuan untuk mendeskripsikan kemampuan literasi kimia mahasiswa di prodi pendidikan kimia UIN Raden Fatah Palembang.

\section{METODE PENELITIAN Jenis Penelitian} kuantitatif.

Penelitian ini merupakan penelitian deskriptif dengan pendekatan

\section{Waktu dan Tempat Penelitian}

Penelitian dilakukan pada bulan Maret-Mei 2018. Penelitian dilakukan di Program Studi Pendidikan Kimia UIN Raden Fatah Palembang.

\section{Subjek Penelitian}

Subjek penelitian merupakan sumber data pada suatu penelitian yang dapat diperoleh keterangannya (Arikunto, 2010: 188), Sampel penelitian ini adalah mahasiswa semester 4 dan mahasiswa semester 6 yang berjumlah 50 orang.

\section{Prosedur Penelitian}

Dalam penelitian ini data diperoleh dari hasil angket yang dibagikan ke mahasiswa yang telah menerima mata kuliah pengelolaan laboratorium. Data yang diperoleh di analisis secara kuantitatif menggunakan statistik deskriptif dengan menghitungan rata-rata hasil penelitian, dibuat dalam bentuk persen (\%) kemudian dijabarkan dalam bentuk tabel dan grafik untuk mempermudah menarik kesimpulan. Wawancara dilakukan ke mahasiswa dan dosen pengampu mata kuliah pengelolaan laboratorium dengan menggunakan pedoman wawancara. Hasil wawancara digunakan hanya untuk memperkuat persepsi mahasiswa mengenai kemampuan literasi kimia terhadap materi pengelolaan limbah.

\section{Teknik dan Instrumen Pengumpul Data}

Teknik pengumpulan data dalam penelitian ini adalah angket dan wawancara. Penyebaranangket dilakukan kepada 50 mahasiswa semester 4 dan 6 yang telah mendapat materipengelolaan laboratorium. Wawancara digunakan sebagaiteknik pengumpulan data untukmenemukan permasalahan yang harusditeliti, dan juga apabila peneliti inginmengetahui hal-hal dari responden secaralebih mendalam (Sugiyono, 2011: 317).Wawancara dilakukan terhadap dosen pengampu mata kuliah pengelolaan laboratorium terkait dengan kemampuan literasi kimia mahasiswa.

Instrumen penelitian ini adalah angket dan wawancara. Angket yang digunakan mengukur 4 aspek literasi kimia yaitu pengetahuan, konteks,kompetensi dan sikap. Masing-masing aspek dijabarkan menjadi 5 
pernyataan sehingga total angket berisi 20 pernyataan yang harus dijawab oleh mahasiswa. Wawancara dipakai untuk mengetahui kemampuan literasi kimia mahasiswa.

Skala pada angket yang digunakan adalah skala likert dengan empat alternatif jawaban. Skala ini disusun dalam suatu bentuk pernyataan dan diikuti oleh pilihan respon yang menunjukkan tingkatan. Pilihan responnya adalah SS (sangat setuju), S (setuju), TS (tidak setuju), dan STS (sangat tidak setuju). Penskoran pilihan jawaban skala likert bergantung pada sifat pernyataan. Untuk pernyataan yang bersifat positif skor jawaban adalah $\mathrm{SS}=4 ; \mathrm{S}=3$; $\mathrm{TS}=2$; $\mathrm{STS}=$ 1. Untuk pernyataan yang bersifat negatif adalahsebaliknya, yaitu $\mathrm{SS}=1 ; \mathrm{S}=2$; $\mathrm{TS}=3 ; \mathrm{STS}=4$

\section{Teknik Analisis Data}

Teknik analisis data yang digunakan untuk mengetahui kemampuan literasi mahasiswa didasarkan pada hasil angket mahasiswa dan didukung dengan hasil wawancara kepada dosen. Kategori kemampuan Literasi kimia dapat dilihat dalam tabel 2.

Tabel 2. Kategori kemampuan literasi Kimia

\begin{tabular}{cc}
\hline Nilai & Kategori Kemampuan \\
\hline$<56$ & Rendah \\
$56-75$ & Sedang \\
$76-100$ & Tinggi \\
\hline & Sumber: Prastiwi,dkk: 2017
\end{tabular}

\section{HASIL DAN PEMBAHASAN}

Berdasarkan hasil penelitian ini diperoleh hasil literasi kimia tiap aspek:

Tabel 3. Hasil Literasi Kimia tiap Aspek

\begin{tabular}{lll}
\hline No & Aspek & Persentase \\
\hline 1 & Pengetahuan (knowledge) & $72,80 \%$ \\
2 & Konteks (context) & $71,30 \%$ \\
3 & Kompetensi (competency) & $71,80 \%$ \\
4 & Sikap (attitudes) & $77,40 \%$ \\
\hline & Rerata & $73,33 \%$ \\
\hline
\end{tabular}

Pada hasil penelitian menunjukkan rerata sebesar $73,33 \%$. Hal ini menunjukkan bahwa kemampuan literasi kimia mahasiswa tergolong sedang. Persentase tiap aspek kemudian dilihat dan dipelajari untuk mengetahui besarnya nilai tiap butir pernyatan. Dimana aspek yang dinilai adalah Pengetahuan (knowledge), Konteks (context), Kompetensi (competency), dan Sikap (attitudes).

\section{a. Aspek Pengetahuan (knowledge)}

Pada aspek pengetahuan ini memasukkan isu-isu personal, lokal/nasional, dan global. Bisa berupa isu-isu yang terjadi saat ini atau isu-isu yang sudah terjadi yang membutuhkan pemahaman sains dan teknologi. Hasil penelitian ini 
menunjukkan butir tiap pernyataan pada angket literasi kimia terdapat pernyataan positif dan negatif. Pada pernyataan positif: nilai paling positif diberi bobot paling besar (karena paling positif berarti paling sesuai harapan). Pada pernyataan negatif: nilai paling negatif diberi bobot paling besar (karena paling negatif berarti paling sesuai harapan). Pada kuesioner penelitian, komposisi bentuk pernyataan positif dan negatif berimbang pada pernyataan aspek pengetahuan terdapat tiga pernyataan positif dan dua pernyataan negatif. Dibawah ini disajikan tabel butir pernyataan aspek pengetahuan:

Tabel 4. Butir Pernyataan Aspek Pengetahuan

1. Saya selalu menggunakan pengetahuan kimia yang berkaitan dengan pencemaran dan pengelolaan limbah dalam memecahkan masalah yang berkaitan tersebut.

2. Saya memahami bagaimana pengelolaan limbah dalam pengelolaan laboratorium diterapkan dalam kehidupan sehari-hari

3. Saya tidak tertarik dengan produk-produk baru dan teknologi baru yang berhubungan dengan materi pengelolaan limbah.

4. Saya tertarik dengan isu-isu yang terkait dengan pencemaran limbah dan pengelolaan limbah.

5. Saya tidak memahami bagaimana pengelolaan limbah dan teknologi berbasis kimia saling berhubungan satu dengan yang lain

Hasil penelitian pada masing-masing pernyataan tersebut, disajikan pada Gambar 1.

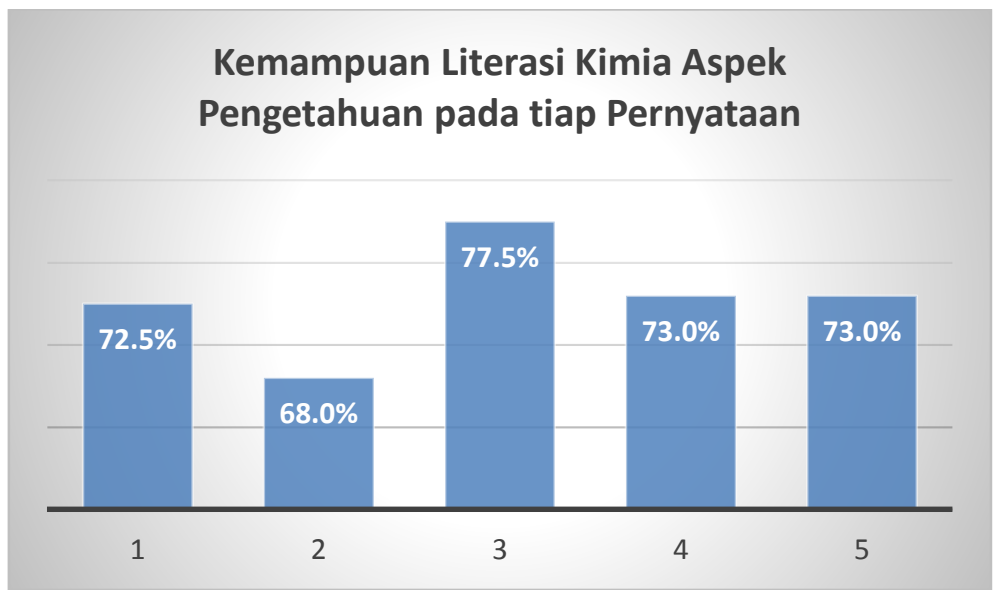

Gambar 1. Kemampuan Literasi Kimia Aspek Pengetahuan pada tiap Pernyataan

Berdasarkan Gambar 1 dapat diperoleh informasi bahwa kemampuan literasi kimia pada aspek pengetahuan dalam pernyataan pengetahuan kimia yang berkaitan dengan pencemaran dan pengelolaan limbah dalam memecahkan masalah sebesar $72,5 \%$ yang tergolong pada kategori "sedang", pada pernyataan pengelolaan limbah dalam pengelolaan laboratorium yang diterapkan dalam kehidupan sehari-hari, isu-isu yang terkait dengan pencemaran limbah dan 
pengelolaan limbah, pengelolaan limbah dan teknologi berbasis kimia saling berhubungan satu dengan yang lain secara bertutut-turut sebesar 68\%, 73\%, dan $73 \%$ tergolong kategori "sedang". Pada pernyataan produk-produk baru dan teknologi baru yang berhubungan dengan materi pengelolaan limbah didapat persentase sebesar 77,5\% tergolong kategori "tinggi". Jika ditinjau secara keseluruhan literasi kimia pada aspek pengetahuan mahasiswa mendapatkan persentase sebesar $72,80 \%$ tergolong kategori "sedang".

b. Aspek Konteks (context)

Pada aspek konteks (context) pada literasi kimia membahas mengenai pemahaman akan fakta-fakta utama, konsep dan teori penjelasan yang membangun landasan pengetahuan ilmiah. Pengetahuan berupa pengetahuan tentang alam semesta dan artefak teknologi, pengetahuan bagaimana gagasangagasan dihasilkan (procedural knowledge), dan pemahaman tentang rasional yang melandasi prosedur tersebut dan justifikasi penggunaannya (epistemic knowledge).Dalam penelitian ini aspek konteks terdapat lima butir pernyataan yang disajikan pada tabel 5.

Tabel 5. Butir Pernyataan Aspek Konteks (context)

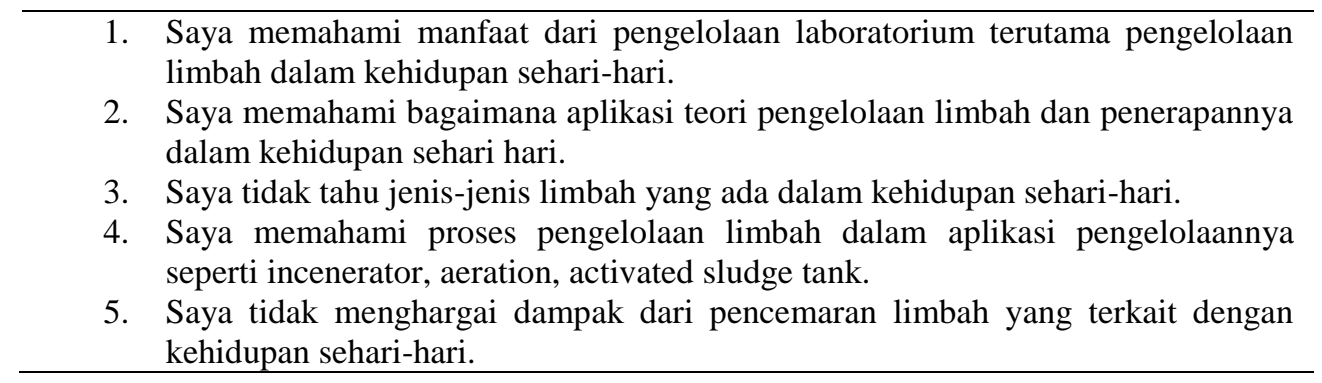

Hasil penelitian pada masing-masing pernyataan tersebut, disajikan pada Gambar 2.

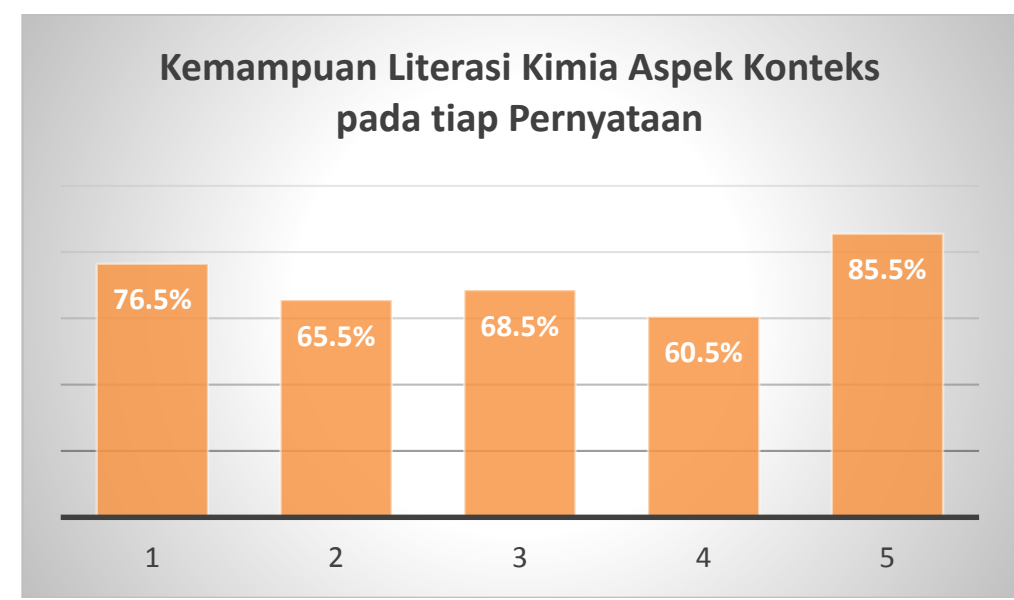

Gambar 2. Kemampuan Literasi Kimia Aspek Konteks pada tiap Pernyataan

Berdasarkan Gambar 2 dapat diperoleh informasi bahwa kemampuan literasi kimia pada aspek konteks. Pada gambar ini ditunjukkan bahwa literasi 
kimia pada aspek konteks pada 3 pernyataan menunjukkan bahwa persentase siswa dibawah $70 \%$ yaitu mengenai aplikasi teori pengelolaan limbah dan penerapannya dalam kehidupan sehari hari, jenis-jenis limbah yang ada dalam kehidupan sehari-hari, pemahaman proses pengelolaan limbah dalam aplikasi pengelolaannya seperti incenerator, aeration, activated sludge tank. Pada pernyataan ini menunjukkan beberapa mahasiswa kurang mengetahui pengelolaan limbah yang terbarukan. Pada pernyataan kelima yaitu kepedulian pada konteks dampak pengelolaan limbah mendapat persentase tertinggi sebesar 85,5\%. Pada pernyataan pengelolaan limbah dalam kehidupan sehari-hari persentasenya juga tergolong kategori tinggi yaitu sebesar $76,5 \%$. Secara keseluruhan pada aspek konteks kemampuan literasi kimia mahasiswa termasuk kedalam kategori sedang dengan persentase $71,30 \%$.

\section{c. Aspek Kompetensi (competency)}

Pada aspek kompetensi (competency) yang termasuk didalamnya adalah kemampuan untuk menjelaskan fenomena secara ilmiah, mengevaluasi dan mendesain inkuiri ilmiah. Terdapat 5 butir pernyataan yang disajikan pada tabel 6 .

Tabel 6. Butir Pernyataan Aspek Kompetensi (competency)

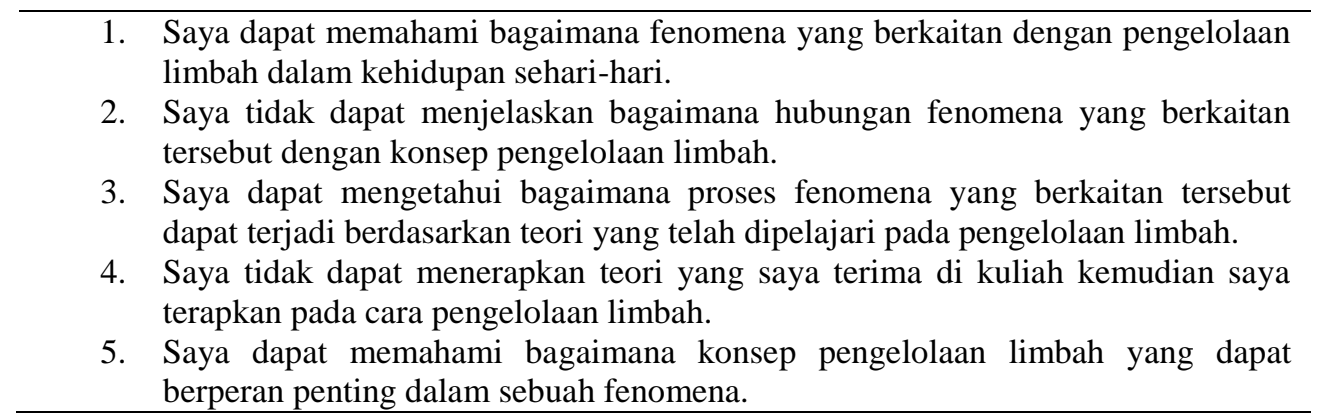
Gambar 3.

Hasil penelitian pada masing-masing pernyataan tersebut, disajikan pada

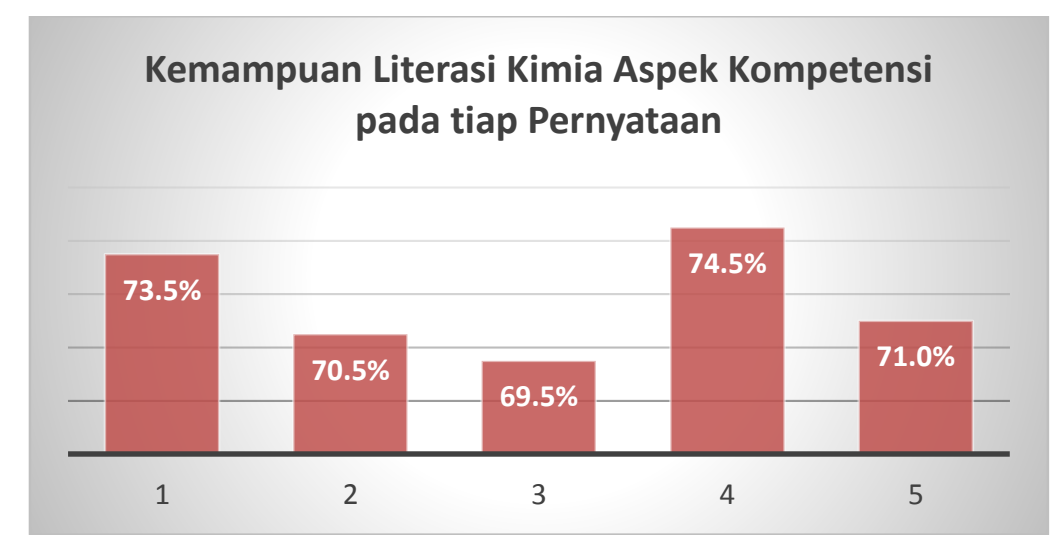

Gambar 3. Kemampuan Literasi Kimia Aspek Kompetensi pada tiap Pernyataan 
Berdasarkan kemampuan literasi kimia mahasiswa pada aspek kompetensi terlihat bahwa pernyataan aspek kompetensi yang paling tinggi dicapai oleh mahasiswa pada penelitian ini adalah pada pernyataan penerapan teori yang diterima pada perkuliahan diterapkan pada cara pengelolaan limbah dengan persentase sebesar $74,5 \%$. Terdapat 3 pernyataan lain yang persentasenya lebih besar dari $70 \%$ yaitu pemahaman mahasiswa fenomena yang berkaitan dengan pengelolaan limbah dalam kehidupan sehari-hari, kejelasan mahasiswa tentang hubungan fenomena yang berkaitan tersebut dengan konsep pengelolaan limbah, dan konsep pengelolaan limbah yang dapat berperan penting dalam sebuah fenomena sekitarnya dengan persentase berurutan sebagai berikut 73,5\%,70,5\%, dan $71 \%$. Dalam aspek ini pernyataan proses fenomena yang berkaitan pada pengelolaan limbah dapat terjadi berdasarkan teori yang telah dipelajari mendapatkan persentase terendah sebesar 69,5\%. Keseluruhan pada aspek kompetensi mahasiswa mendapatkan kategori sedang, dikarenakan tidak ada yang melebihi $75 \%$ pada tiap pernyataan.

Pencapaian kemampuan literasi pada aspek kompetensi menggambarkan kemauan dan kemampuan awal mahasiswa yang nantinya dapat ditarik dalam membuat suatu penafsiran dari suatu fenomena atau kejadian yang dihubungkan dengan teori yang telah dipelajari.

\section{d. Aspek Sikap (attitudes)}

Pada aspek sikap (attitudes) menunjukkanseperangkat sikap terhadap sains yang ditunjukkan dengan minat terhadap sains dan teknologi, menilai pendekatan ilmiah terhadap suatu inkuiri yang cocok, dan persepsi serta kesadaran akan isuisu lingkungan. Terdapat 5 butir pernyataan yang disajikan pada tabel 7

Tabel 7. Butir Pernyataan Aspek Aspek Sikap (attitudes)

1. Saya selalu membuang limbah sesuai dengan aturan yang ditetapkan pemerintah.

2. Saya tertarik dalam pengelolaan limbah yang terbarukan karena lebih efisien.

3. Saya tidak tertarik dalam mengolah limbah agar menjadi bahan yang dapat dimanfaatkan kembali.

4. Saya suka membaca dan belajar mengenai jurnal pengelolaan limbah .

5. Saya tidak memilah-milah limbah berdasarkan jenisnya sebelum saya buang.

Hasil penelitian pada masing-masing pernyataan tersebut, disajikan pada Gambar 4. Kemampuan Literasi Kimia Aspek Sikap pada tiap Pernyataan. 


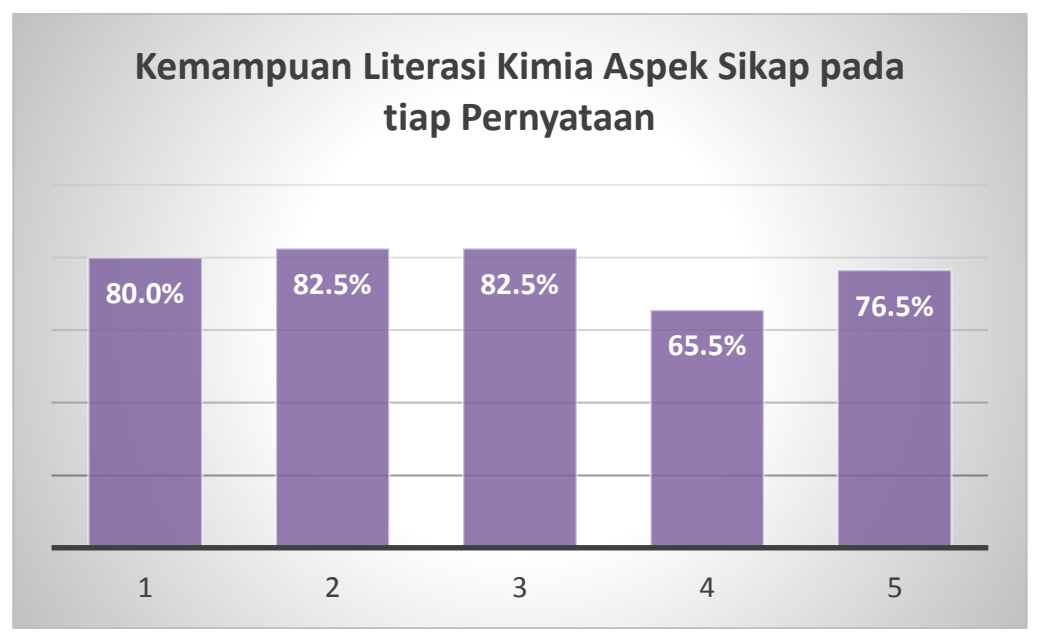

Gambar 4. Kemampuan Literasi Kimia Aspek Sikap pada tiap Pernyataan

Pada aspek sikap (attitudes) jika ditinjau secara keseluruhan,persentase adalah $77.75 \%$ dimana tergolong memiliki sikap (attitudes) yang tinggi terhadap pengelolaan limbah, akan tetapi dapat dilihat bahwa pada pernyataan keempat dimana menyatakan ketertarikan mereka pada minat membaca jurnal sebesar 65,5\%. Jurnal disini merupakan jurnal tentang pengelolaan limbah dan pencemaran limbah dimana terdapat banyak sekali penelitian terkait materi ini. Jika dilihat dari gambar tersebut persentase ketiga pernyataan tentang pembuangan limbah yang sesuai aturan pemerintah, ketertarikan pada pengeloaan limbah yang efisien dan pengelolaan limbah menjadi bahan yang dapat dimanfaatkan secara berturut - turut adalah $80 \%, 82,5 \%, 82,5 \%$ dimana tergolong tinggi. Pada pernyataan 5 secara persentase menunjukkan nilai $76,5 \%$ tergolong tinggi tapi kebanyakan mahasiswa masih bingung bagaimana memilah limbah dengan benar karena ketersediaan tempat pembuangan yang masih dirasa belum terpisah. Mahasiswa kebanyakan masih mengganggap barang yang sudah terpakai adalah limbah dan dibuang pada tempat yang sama. Padahal limbah memiliki berbagai jenis limbah yang dapat ditemukan dalam kehidupan sehari-hari misalnya limbah organik dan an organik.

Dalam penelitian ini juga dilakukan wawancara terhadap dosen pengampu mata kuliah pengelolaan laboratorium khususnya pada materi pengelolaan limbah. Pada wawancara yang dilakukan terdapat beberapa hal penting terkait literasi kimia calon pendidik atau mahasiswa pendidikan kimia. Pada wawancara ini dapat di identifikasi minat dari mahasiswa dalam membaca atau berliterasi dimana secara umum mahasiswa haruslah dipaksa terlebih dulu agar mau membaca. Pada perkuliahan sebenarnya dosen pengampu sudah memancing stimulus literasi mahasiswa, akan tetapi kesulitan dalam berbahasa asing juga menjadi kendala dikarenakan banyak literasi dari luar negeri yang menggunakan bahasa inggris sehingga kurang menarik minat membaca dari mahasiswa. Isu-isu dan penerapan fenomena pengelolaan limbah yang terbarukan jadi kurang dapat dipahami dengan baik oleh mahasiswa. Pelaksanakan pencapaian kemampuan literasi kimia mahasiswa, juga terdapat kendala pada aktivitas mengamati maupun mengaitkan 
materi perkuliahan terhadap fenomena yang terjadi di kehidupan sehari-hari karena pada penerapannya praktek lapangan belum dapat dilakukan sehingga stimulus yang dapat membangun pengetahuannya yang menghubungkan fakta dan materi tidak dapat berjalan. Pada kegiatan evaluasi di akhir penyampaian materi pengelolaan limbah, calon pendidik sebenarnya sudah diperkenalkan dengan soal/tes yang berorientasi pada peningkatan kemampuan literasi kimia, sesuai dengan pernyataan prastiwi (2017) kegiatan evaluasi di akhir penyampaian materi pembelajaran, peserta didik perlu diperkenalkan dengan dengan soal/tes yang berorientasi pada peningkatan kemampuan literasi kimia.Pembelajaran yang dilakukan perlu melatihkan keterampilan-keterampilan sains sehingga peserta didik terbiasa melakukan hal-halyang berhubungan dengan kegiatan seperti: memberikan penjelaskan fenomena secara ilmiah, menggunakan pemahaman kimia dalam memecahkan masalah, dan menganalisis manfaat dari aplikasi kimia.

Pada materi pengelolaan limbah, banyak topik yang dapat dihubungkan dan diaplikasikan pada kehidupan sehari-hari. Pengembangan kemampuan literasi kimia pada pengelolaan limbah dapat dilihat contohnya adalah pengelolaan limbah plastik. Topik tersebut dapat dibuat menjadi suatu cerita yang menggambarkan ketersediaan plastik dalam kehidupan sehari-hari, bagaimana cara menangani plastik yang sudah tidak terpakai, apakah limbah berbahan plastik dapat didaur ulang, bagaimana cara mendaur ulangnya dan apa produk yang dihasilkan dari daur ulang limbah tersebut yang dapat dibuat sebuah studi kasus yang diberikan kepada mahasiswa. Mahasiswa diminta untuk menentukan bagaimana pengelolaan limbah plastik ini berdasarkan jenis-jenis plastik. Dalam mengukur literasi kimia dapat menggunakan pengukuran literasi sains yang memperhatikan kriteria pembuatan soal literasi sains Program for International Student Assessment (PISA), sehingga kemampuan literasi sains peserta didik di Indonesia menjadi lebih baik dan dapat berpartisipasi di dunia industri dunia serta memiliki kualitas yang sama.

\section{KESIMPULAN}

Berdasarkan hasil dan pembahasan dapat disimpulkan bahwa kemampuan literasi kimia mahasiswa pendidikan kimia masih sedang. Saran untuk penelitian ini adalah Penelitian ini baru dilakukan sampai tahap pra penelitian (survey) yang terbatas sehingga penulis mengaharapkan peneliti lain dapat melanjutkan penelitian ini sampai tahap akhir menggunakan subjek penelitian yang lebih luas.

\section{DAFTAR RUJUKAN}

Arikunto, Suharsimi. (2006). MetodologiPenelitian. Yogyakarta: BinaAksara.

Lederman, N.G. 2014. Nature of science and its fundamental important to the vision of the next generation science standars. Science \& Children, 8-10.

OECD. (2016). PISA 2015 Results in Focus. Oecd, (67), 16. https://doi.org/10.1787/9789264266490-en 
Organization for Economic Co-operation and Development. 2000. Programme For Programme For International Student International Student Assessment and Non-OECD Assessment and Non-OECD Countries Countries. Diperoleh 9 Maret 2018, dari http://www.oecd.org/edu/school/program meforinternationalstudentassessmentpisa/33690591.pdf.

Organization for Economic Co-operation and Development. 2003. Chapter 3 of the Publication "PISA 2003 Assesment of framework - mathematics, Reading, Science and Problem Solving Knowledge and Skills. Diperoleh 9 Maret 2018, dari http://www.oecd.org/dataoecd/38/29/33707226.pdf.

Organization for Economic Co-operation and Development. 2003. Literacy Skills for the World of Tomorrow. Further Result from PISA 2000. Diperoleh 9 Maret 2018, dari http://www.oecd.org/edu/school/programmeforinternationalstudentassessmen tpisa/33690591.pdf.

Organization for Economic Co-operation and Development (OECD-PISA)(last revised 2005), Assessment of scientific literacy in the OECD/Pisa project, http://www.pisa.oecd.org/

Organization for Economic Co-operation and Development. 2009. PISA 2009 Assessment Framework, Key Competences in Reading, Mathematic and Science. Diperoleh 92018 Mahasiswa dari http://www.oecd.org/pisa/pisaproducts/44455820.pdf.

Organization for Economic Co-operation and Development. 2009. Take the Test. Sample Questions from OECD's PISA Assessments. Diperoleh 9 Maret 2018, dari http://browse.oecdbookshop.org/oecd/pdfs/free/9809051e.pdf.

Organization for Economic Co-operation and Development. 2012. Results Students and Money Financial Literacy Skills For The 21st Century Volume VI. Diperoleh 9 Maret 2018. http://www.oecd.org/pisa/keyfindings/PISA2012-results-volume-vi.pdf.

Organization for Economic Co-operationand Development (OECD-PISA).2016. Assessment of scientificliteracy in the OECD / Pisa project,http://www.pisa.oecd.org/

Prastiwi, M.N.B, Rahmah, N, Khayati N, Utami D.P, Primastuti M, Majid A.N. (2017). Studi Kemampuan Literasi Kimia Peserta Didik Pada Materi. Prosiding Seminar Nasional Kimia UNY 2017, 21, 183-188.

Sugiyono. (2011). Metode Penelitian Pendidikan (Pendekatan Kuantitatif, Kualitatif, dan R\&D). Bandung: Alfabeta. 
Sumartati, L. (2009). Pembelajaran IPA terpadu pada tema makanan dan pengaruhnya terhadap kerja ginjal untuk meningkatkan Literasi Sains siswa MTs. Thesis. Sekolah Pascasarjana UPI

Shwartz Y., Ben-Zvi R. and Hofstein A. (2005). The importance of involving high-school chemistry teachers in the process of defining the operational meaning of 'chemical literacy'. International Journal of Science Education, 27(3), 323-344

Shwartz Y., Bez-Zvi R. and Hofstein A.(2006). The use of scientific literacy taxonomy for assessing the development of chemical literacy among highschool students. Chemistry Education Research \& Practice, 7(4), 203-225. 